\title{
HYDROGEOCHEMICAL ASSESSMENT OF GROUNDWATER OF IGBOORA AREA, SOUTHWESTERN NIGERIA
}

\author{
AKANBI, O. A., SANNI, W., OSHIN, O., AND OLATUNDE, A. G.
}

(Received 12 September 2019; Revision Accepted 3 July 2020)

\begin{abstract}
The people of Igboora rely on groundwater for their domestic water supply. A hydrogeochemical study was carried out on twenty-seven groundwater samples collected from various boreholes across the study area to determine the suitability of the groundwater for drinking purpose. The total dissolve solids (TDS), electrical conductivity (EC) and pH of the water were measured in the field directly, while the concentrations of major ions were done in the laboratory using flame photometry and spectrophotometry methods. The hydrogeochemical facies classes was done with piper plot and the likely enrichment source(s) of the chemical facies were interpreted with Gibbs plot in conjunction with correlation analysis. The results showed that the $\mathrm{pH}$ was between 5.0 and 6.7 at an average (av.) of 5.8; TDS ranged from $50-280$ (av. 183) $\mathrm{mg} / \mathrm{L}$ and EC was $110-560$ (av. 373) $\mu \mathrm{S} / \mathrm{cm}$. The concentrations of the major cations in $\mathrm{mg} / \mathrm{L}$ were: $5-105.5 \mathrm{Ca}^{2+}, 1-11.9 \mathrm{Mg}^{2+}, 0-95 \mathrm{Na}^{+}, 0-112 \mathrm{~K}^{+}$, while for anions the ranges were, $9-58 \mathrm{HCO}_{3}^{-}, 6.8-$ $28.8 \mathrm{CO}_{3}{ }^{2-}, 1.1-29.4 \mathrm{SO}_{4}{ }^{2-}, 2.9-26 \mathrm{Cl}^{-}$and $16-90.5$ for $\mathrm{NO}_{3}{ }^{-}$. From the mean values, the order of the cationic dominance was $\mathrm{Ca}^{2+}>\mathrm{K}^{+}>\mathrm{Na}^{+}>\mathrm{Mg}^{2+}$ while that of anionic was $\mathrm{NO}_{3}^{-}>\mathrm{HCO}_{3}^{-}>\mathrm{CO}_{3}{ }^{2-}>\mathrm{Cl}^{-}>\mathrm{SO}_{4}{ }^{2-}$. The hydrogeochemical facies in the groundwater was mainly $\mathrm{Ca}-\mathrm{HCO}_{3}$ type with minor occurrences of $\mathrm{Na}-\mathrm{HCO}_{3}$ and $\mathrm{Ca}$ $\mathrm{Na}-\mathrm{HCO}_{3}$ types. Enrichment source of the cationic chemical facies was mainly rock dominated, while that of the anionic were from meteoric and biogenic sources. From the results of correlation analyses, the TDS has direct and positive relationships with most chemical constituents, indicating that the analysed ionic constituents dominated the dissolved solids in the groundwater. The groundwater can be said to be potable except that the water in the boreholes is slightly acidic and nitrate concentration exceeded recommended limit of $50 \mathrm{mg} / \mathrm{L}$ in many of the samples.
\end{abstract}

\section{INTRODUCTION}

Groundwater is the main source of potable water supply for domestic, industrial and agricultural purposes in developing nation like Nigeria where piped-borne water supply is no longer reliable and, in most cases, unavailable (Fashae, et. al., 2014; Akanbi, 2018). Though, many researches in Nigeria focused on the occurrence of groundwater within the subsurface environment, however; no matter how prolific the groundwater zone may be, the quality of the enclosed water can constitute a major setback for water usage, even for modest application. The chemical characterisation of the groundwater system is an essential investigation of any groundwater development and management scheme. This is because the chemical constituents of groundwater are not only affected and modified by mineral dissolution of the host rocks (aquifers), it is also largely affected by direct recharge from surface effluents and chemical nature of the recharging water and interactions along soil units during infiltration of water.

\section{Location of the Study Area}

The study area (Igboora and Environs) lies within latitude $7^{0} 24^{\prime} 45^{\prime \prime} \mathrm{N}-07^{\circ} 26^{\prime} 45^{\prime \prime} \mathrm{N}$, and longitude $03^{\circ} 16^{\prime}$ $30^{\prime \prime}-03^{0} 18^{\prime} 45^{\prime \prime} \mathrm{E}$ (Fig. 1) in Ibarapa region of Oyo state located in southwestern (SW) Nigeria. In Igboora community, shallow groundwater constitutes the predominant source of public water supply through the use of hand pump borehole (Akanbi, 2017). Igboora and its environs were hit by series of water-borne diseases in the 1980 s as a result of lack of potable and reliable water supply. This made the government to embark on numerous groundwater drilling project in most parts of Ibarapa region, where Igboora is one of the major towns (Akanbi, 2016).

\section{Geology and Hydrogeology of the Area}

Igboora lies within the SW Nigerian basement terrain whose bedrocks have been dated to be Precambrian Age (Dada, 1998, NGSA, 2009). The principal crystalline rock units that underlie Igboora are mainly schistose and massive amphibolites (Figure 1), with quartzite and quartz schist intercalations (Akanbi, 2017). Amphibolites

Akanbi, O. A., Department of Earth Sciences, Ajayi Crowther University, Oyo, Oyo Town Nigeria.

Sanni, W., Department of SLT/Geology, The Polytechnic Ibadan, Ibadan Nigeria.

Oshin, O., Department of Earth Sciences, Ajayi Crowther University, Oyo, Oyo Town Nigeria.

Olatunde, A. G., Formerly Ajayi Crowther University, Oyo Town, Nigeria. 
are medium grained, melanocratic crystalline rocks of metamorphic origin that composed primarily of hornblende and plagioclase, and very little quartz. The foliated variety of amphibolite is the amphibolite-schist. Due to large amount of ferromagnesian mineral assemblage, amphibolites are more susceptible to weathering and dissolution than any other crystalline rocks in the area, which included gneisses, migmatite and granite (Fig. 1).

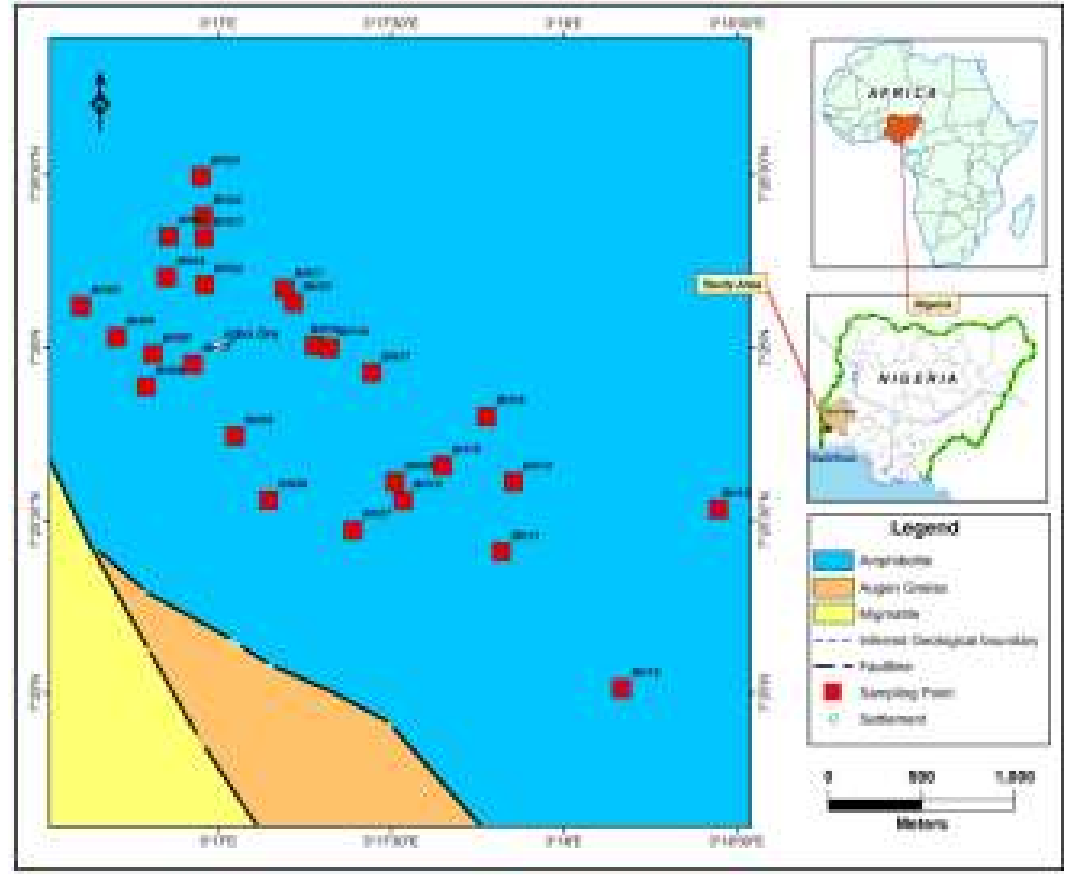

Figure 1: Geological map showing the locations of the sampled boreholes in the study area

Hydrogeological characteristics and groundwater prospect of the basement aquifers of most parts of Ibarapa region have been studied and it has been found that areas underlain by amphibolites including Igboora township have more potential for sustainable groundwater supply than others areas in this region (Akanbi, 2018). However, basement aquifers are found to occur at shallow depth and may be liable to contamination (Egboka, 1987; Tijani, 2016; Akanbi, 2017; Akinwumiju, et al., 2018; Oyedele et al., 2019). Thus, in order to safeguard the well-being of tens of thousands of humans that rely on this shallow groundwater system, there is a need to assess the physico-chemical and major element concentrations of the shallow aquifers of the area.

\section{METHODOLOGY}

\section{Sampling and Measurement of Supplementary Water Parameters}

Groundwater samples were collected from twenty-seven boreholes scattered across Igboora township area as presented in Figure 1. The depths of the sampled wells range between 19 and $30 \mathrm{~m}$ (Akanbi, 2017). Sampling was carried out in the month of January during the dry season when the effects of dilution due to surface water infiltration is minimal. Physico-chemical parameters such as $\mathrm{pH}$, electrical conductivity (EC), and total dissolved solids (TDS) were measured immediately in the field using Milwaukee Sm801 pH/EC/TDS meter.

\section{Major lons Analyses}

Major cations and anions including $\mathrm{Na}^{+}, \mathrm{K}^{+}, \mathrm{Ca}^{2+}, \mathrm{Mg}^{2+}$, $\mathrm{Cl}^{-}, \mathrm{CO}_{3}{ }^{2-}, \mathrm{HCO}_{3}{ }^{-}$and $\mathrm{SO}_{4}{ }^{2-}$ were analysed in GAAS laboratory in lbadan and reported in $\mathrm{mg} / \mathrm{L}$. Anions were analysed using the Jenway Aquanova Spectrophotometer. The parameters were selected from the test manager of the spectrophotometer. Two $10 \mathrm{ml}$ sample cells were filled with the sample to be tested and 1 pillow (reagent) of test parameter was added to one of the sample in the sample cell and thoroughly shaken. The sample was allowed to stay for some time for reaction to take place depending on the test parameter. The sample bottle that contain blank was first introduced into the sample chamber to calibrate the machine for the tested parameter, after which the sample cell of investigating sample was introduced. The concentration of the test parameter in $\mathrm{mg} / \mathrm{L}$ was displayed on the spectrophotometer screen. For chloride, the reagents used were $2.0 \mathrm{ml}$ mercuric thiocyanate and $1.0 \mathrm{ml}$ Ferric iron solution, while carbonate and bicarbonate were determined using phenolphthalein alkalinity and total alkalinity respectively. The cations were analysed with Jenway Flame Photometer. Each sample was introduced into the flame through an inlet hose, in which the Photometer has been calibrated by series of known standard of the tested parameters, the concentration of individual tested parameter is read on the screen as displayed. 
Data Interpretation and Evaluation

Hydrogeochemical classification of groundwater was done using Piper plot (Piper, 1944). The analysed variables in $\mathrm{mg} / \mathrm{L}$ were converted to milliequivalent $/ \mathrm{L}$ $(\mu \mathrm{eq} / \mathrm{L})$ and the percentage ratio of each ion upon the total cations/anions was estimated. The percentage values were plotted in Piper diagram using Gw_chart software to obtain the hydrogeochemical facie group that each water sample belongs. Gibbs diagram was also plotted for interpreting the sources of the chemical constituents in the groundwater. Gibbs (1970) enunciated that hydrogeochemical facies in world waters can be from the rock or aquifer and weathering source, or can either be precipitation or evaporation dominated. Evaluation of variables was carried out to interpret the inter-dependence of certain parameters using correlation analyses to establish how variables compare with each one with a certain confidence interval.

\section{RESULTS}

Results of the analysed parameters in groundwater samples are presented in Table 1. Descriptive statistics and guidelines of standard organization of Nigeria, SON (2007) and World Health Organization, WHO (2011) for drinking water as well as toxic effects of each variable on human health are presented in Table 2.

From the results, the $\mathrm{pH}$ value of groundwater samples ranges from 5.0 to 6.7 and the average is 5.8 . From the average value the water is slightly acidic. The total dissolved solids (TDS) which is a strong indicator of the degree of water freshness/salinity and suitability for domestic use was between 50 and $280 \mathrm{mg} / \mathrm{L}$. The electrical conductivity (EC) ranges from 110 to 560 with a mean of 373 micosiemens. For major cations, calcium which is the most common ions in subsurface water (Davis and Dewiest, 1966) is also the most dominant in the groundwater of the area with concentration range between 5.0 and $105.5 \mathrm{mg} / \mathrm{L}$ and average of $52.6 \mathrm{mg} / \mathrm{L}$. Potassium ion $\mathrm{K}^{+}$which is an essential mineral component for humans occurred below detection limit in four boreholes. The highest occurrence of potassium was $112 \mathrm{mg} / \mathrm{L}$ in $\mathrm{BH} 13$ and the average concentration was $38.3 \mathrm{mg} / \mathrm{L}$, Sodium occurrence is scanty in the areas and occurred below detection limits in eight locations. The highest concentration of sodium was 95 $\mathrm{mg} / \mathrm{L}$ in $\mathrm{BH} 17$. Magnesium ion concentrations were below $12 \mathrm{mg} / \mathrm{L}$ in all the wells. The highest concentration was $11.9 \mathrm{mg} / \mathrm{L}$ in $\mathrm{BH} 03$, while the mean value was 7.3 $\mathrm{mg} / \mathrm{L}$.

Nitrate is the most dominant anions in the groundwater of the area. It occurred between $16 \mathrm{mg} / \mathrm{L}$ in $\mathrm{BH} 16$ and $90.5 \mathrm{mg} / \mathrm{L}$ in $\mathrm{BH} 13$. Nitrate occurred at significant levels that exceeded $50 \mathrm{mg} / \mathrm{L}$ in nine locations. The average concentration was $43.9 \mathrm{mg} / \mathrm{L}$, which is regarded to be high considering the fact that nitrate enrichment is not from naturally dissolution of rocks. Bicarbonate is the next abundant anions with a range of $9-58 \mathrm{mg} / \mathrm{L}$ and a mean of $18.3 \mathrm{mg} / \mathrm{L}$. 
AKANBI, O. A., SANNI, W., OSHIN, O., AND OLATUNDE, A. G.

Table 1: Results of measured and analysed parameters in sampled boreholes

\begin{tabular}{|c|c|c|c|c|c|c|c|c|c|c|c|c|}
\hline $\begin{array}{l}\text { Sample } \\
\text { No }\end{array}$ & $p^{H}$ & EC & TDS & $\mathrm{Ca}^{2+}$ & $\mathrm{Mg}^{2+}$ & $\mathrm{Na}^{2+}$ & $\mathrm{K}^{+}$ & $\mathrm{HCO}_{3}{ }^{-}$ & $\mathrm{CO}_{3}{ }^{2-}$ & $\mathrm{SO}_{4}{ }^{2-}$ & $\mathrm{NO}_{3}^{-}$ & $\mathrm{Cl}^{-}$ \\
\hline & & $(\mu \mathrm{S} / \mathrm{cm})$ & \multicolumn{10}{|c|}{$M g / L$} \\
\hline $\mathrm{BH} 01$ & 6.0 & 460 & 220 & 58.5 & 1.2 & ND & 60 & 26 & 13.1 & 5.7 & 60.3 & 15.0 \\
\hline $\mathrm{BH} 02$ & 6.7 & 370 & 180 & 42.9 & 7.3 & ND & 88 & 15 & 11.3 & 3.8 & 47.8 & 15.0 \\
\hline $\mathrm{BH} 03$ & 6.5 & 360 & 180 & 37.5 & 11.9 & ND & 36 & 10 & 8.8 & 2.6 & 44.6 & 14.0 \\
\hline $\mathrm{BH} 04$ & 5.5 & 510 & 260 & 64.0 & 9.2 & ND & 60 & 14 & 10.9 & 3.8 & 65.3 & 15.0 \\
\hline $\mathrm{BH} 05$ & 6.5 & 400 & 190 & 55.7 & 9.2 & 42.0 & 48 & 23 & 10.3 & 2.2 & 62.1 & 19.0 \\
\hline $\mathrm{BH} 06$ & 5.9 & 380 & 190 & 33.8 & 8.9 & 26.0 & 40 & 32 & 12.6 & 5.7 & 35.9 & 6.4 \\
\hline $\mathrm{BH} 07$ & 6.0 & 370 & 180 & 38.4 & 7.3 & 12.0 & 80 & 25 & 13.4 & 11.5 & 50.5 & 14.0 \\
\hline $\mathrm{BH} 08$ & 5.7 & 190 & 90 & 35.9 & 1.0 & 81.0 & ND & 23 & 6.8 & 9.2 & 35.2 & 7.8 \\
\hline $\mathrm{BH} 09$ & 5.5 & 490 & 240 & 85.4 & 9.3 & ND & 60 & 28 & 28.8 & 29.4 & 64.8 & 10.0 \\
\hline $\mathrm{BH} 10$ & 5.5 & 360 & 180 & 71.3 & 7.5 & 15.0 & 32 & 14 & 12.6 & 6.7 & 64.5 & 8.6 \\
\hline $\mathrm{BH} 11$ & 5.9 & 200 & 100 & 11.9 & 5.4 & 32.0 & 48 & 12 & 8.4 & 3.8 & 36.8 & 8.0 \\
\hline $\mathrm{BH} 12$ & 6.0 & 110 & 50 & 7.3 & 1.0 & 66.0 & ND & 14 & 7.3 & 1.1 & 16.0 & 2.9 \\
\hline $\mathrm{BH} 13$ & 6.5 & 560 & 280 & 105.5 & 6.9 & 6.0 & 112 & 58 & 16.8 & 12.3 & 90.5 & 26.0 \\
\hline $\mathrm{BH} 14$ & 5.6 & 300 & 140 & 23.8 & 6.8 & 9.0 & 40 & 12 & 10.1 & 3.4 & 40.2 & 8.6 \\
\hline $\mathrm{BH} 15$ & 6.0 & 435 & 210 & 74.9 & 9.3 & 27.0 & 32 & 15 & 13.4 & 6.2 & 50.5 & 14.0 \\
\hline $\mathrm{BH} 16$ & 5.1 & 300 & 150 & 63.4 & 8.5 & ND & 42 & 10 & 12.6 & 6.7 & 51.2 & 13.0 \\
\hline $\mathrm{BH} 17$ & 6.0 & 160 & 80 & 5.0 & 3.1 & 95.0 & ND & 13 & 8.4 & 1.3 & 32.0 & 4.1 \\
\hline $\mathrm{BH} 18$ & 5.8 & 430 & 210 & 76.8 & 8.7 & ND & 26 & 11 & 17.6 & 10.4 & 45.6 & 6.8 \\
\hline $\mathrm{BH} 19$ & 5.5 & 540 & 270 & 78.5 & 10.1 & ND & 32 & 14 & 16.0 & 4.8 & 37.3 & 6.5 \\
\hline $\mathrm{BH} 20$ & 6.0 & 450 & 220 & 71.3 & 7.3 & 16.0 & 24 & 10 & 14.7 & 5.3 & 34.0 & 7.4 \\
\hline $\mathrm{BH} 21$ & 6.5 & 410 & 210 & 52.1 & 4.5 & 4.0 & 56 & 14 & 11.2 & 7.8 & 48.1 & 6.6 \\
\hline $\mathrm{BH} 22$ & 6.0 & 260 & 120 & 23.7 & 8.4 & 64.0 & 40 & 14 & 8.4 & 2.8 & 32.7 & 8.8 \\
\hline $\mathrm{BH} 23$ & 5.0 & 430 & 210 & 66.3 & 10.9 & 6.0 & 34 & 14 & 13.4 & 10.2 & 23.3 & 12.0 \\
\hline $\mathrm{BH} 24$ & 5.2 & 520 & 260 & 98.2 & 9.8 & 8.0 & 32 & 22 & 14.7 & 12.0 & 47.0 & 15.0 \\
\hline $\mathrm{BH} 25$ & 5.0 & 420 & 200 & 73.1 & 8.0 & 20.0 & 8 & 18 & 20.6 & 21.1 & 28.4 & 21.0 \\
\hline $\mathrm{BH} 26$ & 5.0 & 380 & 190 & 58.5 & 11.7 & 4.0 & 4 & 9 & 10.7 & 8.8 & 18.1 & 11.0 \\
\hline $\mathrm{BH} 27$ & 6.0 & 280 & 130 & 7.3 & 2.6 & 68.0 & ND & 24 & 7.6 & 1.9 & 23.5 & 7.6 \\
\hline
\end{tabular}

ND. Not detected

Table 2: Descriptive Statistics, Drinking Water Guidelines and Health Effect

\begin{tabular}{|l|l|l|l|l|l|l|}
\hline Parameters & Min. & Max. & Mean & $\begin{array}{l}\text { Nigerian } \\
\text { guideline } \\
\text { sON (2007) }\end{array}$ & $\begin{array}{l}\text { WHO } \\
\text { guideline } \\
\text { (2011) }\end{array}$ & Health effect on human \\
\hline $\mathrm{pH}$ & 5.0 & 6.7 & 5.8 & $6.5-8.5$ & $6.5-8.5$ & Not pertinent \\
\hline $\mathrm{EC}(\mu \mathrm{S} / \mathrm{cm})$ & 110.0 & 560.0 & 373.1 & - & 1500 & Not pertinent \\
\hline $\mathrm{TDS}(\mathrm{mg} / \mathrm{L})$ & 50.0 & 280.0 & 183.0 & 500 & 1000 & Unpalatable taste \\
\hline $\mathrm{Ca}^{2+}(\mathrm{mg} / \mathrm{L})$ & 5.0 & 105.5 & 52.6 & - & 2500 & Kidney stone formation \\
\hline $\mathrm{Mg}^{2+}(\mathrm{mg} / \mathrm{L})$ & 1.0 & 11.9 & 7.3 & - & $250-350$ & Osmotic diarrhoea \\
\hline $\mathrm{Na}^{+}(\mathrm{mg} / \mathrm{L})$ & 0.0 & 95.0 & 22.3 & 200 & 200 & Unacceptable taste \\
\hline $\mathrm{K}^{+}(\mathrm{mg} / \mathrm{L})$ & 0.0 & 112.0 & 38.3 & - & - & Not pertinent \\
\hline $\mathrm{HCO}_{3}{ }^{-}(\mathrm{mg} / \mathrm{L})$ & 9.0 & 58.0 & 18.3 & - & 100 & Not pertinent \\
\hline $\mathrm{CO}_{3}{ }^{2-}(\mathrm{mg} / \mathrm{L})$ & 6.8 & 28.8 & 12.6 & - & - & Not pertinent \\
\hline $\mathrm{SO}_{4}{ }^{2-}(\mathrm{mg} / \mathrm{L})$ & 1.1 & 29.4 & 7.4 & 100 & 500 & Laxative effect \\
\hline $\mathrm{NO}_{3}{ }^{-}(\mathrm{mg} / \mathrm{L})$ & 16.0 & 90.5 & 43.9 & 50 & 50 & Methaemoglobinaemia in infants \\
\hline $\mathrm{Cl}^{(}(\mathrm{mg} / \mathrm{L})$ & 2.9 & 26.0 & 11.3 & 250 & 250 & Detectable taste \\
\hline
\end{tabular}


Bicarbonate is associated with dissolution of carbon IV oxide in atmospheric water to form carbonic acid that latter dissociate to bicarbonate and hydrogen ions in natural waters. Carbonate is also fairly represented in the sampled water with a range of $6.8-28.8 \mathrm{mg} / \mathrm{L}$ and a mean of $12.6 \mathrm{mg} / \mathrm{L}$. Although, bicarbonate and carbonate are fairly represented in the groundwater samples, their concentrations are not a concern for human health (WHO, 2011). Chloride concentration was between 2.9 and $26 \mathrm{mg} / \mathrm{L}$ with an average of $11.3 \mathrm{mg} / \mathrm{L}$. Chloride concentrations are far below the significant level (Table 2). Lastly, sulphate concentration was between 1.1 and $29.4 \mathrm{mg} / \mathrm{L}$ and a mean of $7.4 \mathrm{mg} / \mathrm{L}$. From the average concentrations (Table 2), the dominance order of the cationic constituents is $\mathrm{Ca} 2+>$
$\mathrm{K}+>\mathrm{Na}+>\mathrm{Mg} 2+$ while the anionic dominance is NO3$>\mathrm{HCO}_{3-}>\mathrm{CO}_{3}{ }^{-2}->\mathrm{Cl}->\mathrm{SO}_{4}{ }^{2-}$.

From the Piper plot (Fig. 2), the groundwater is predominantly $\mathrm{Ca}-\mathrm{HCO}_{3}$ type (type 3). Other water types represented are $\mathrm{Ca}-\mathrm{Na}-\mathrm{HCO}_{3}$ and $\mathrm{Na}-\mathrm{HCO}_{3}$ facies respectively. The occurrence of $\mathrm{Ca}-\mathrm{HCO}_{3}$ was $74 \%$, while the frequency of occurrences of the other two types are equal and $8 \%$ each. In the cationic base triangle (Fig. 2), the dominant cation in many samples is calcium, about six fell within potassium and sodium dominant zone, while the rest of the samples plotted within the mixed types with no dominant cations. However, for anions, bicarbonate and carbonate are the only dominant water facies in all the samples (Fig. 2).

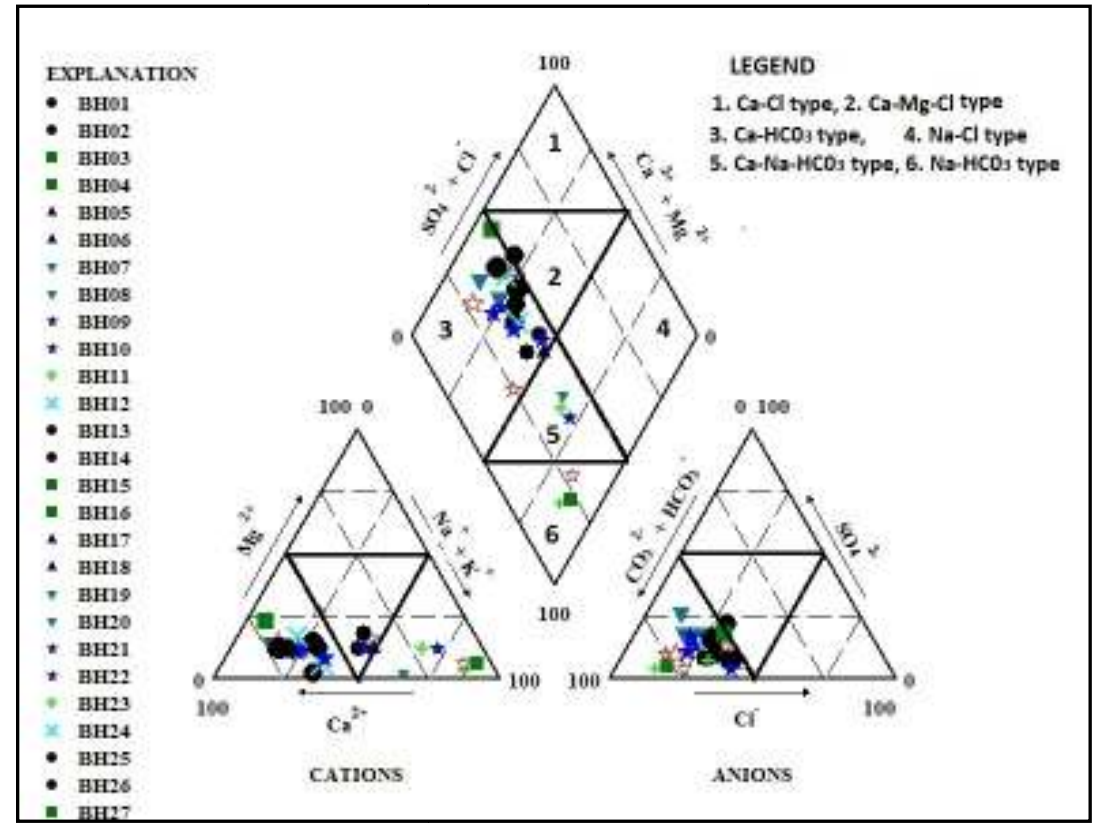

Figure 2: Hydrogeochemical facies classes in groundwater of the study area

The Gibbs plot that indicated enrichment source(s) of the hydrogeochemical facies is presented in Figure 3. It showed that majority of the samples plotted within rock dominated region though some fell along the boundary of precipitation and rock dominance in Gibbs diagram.

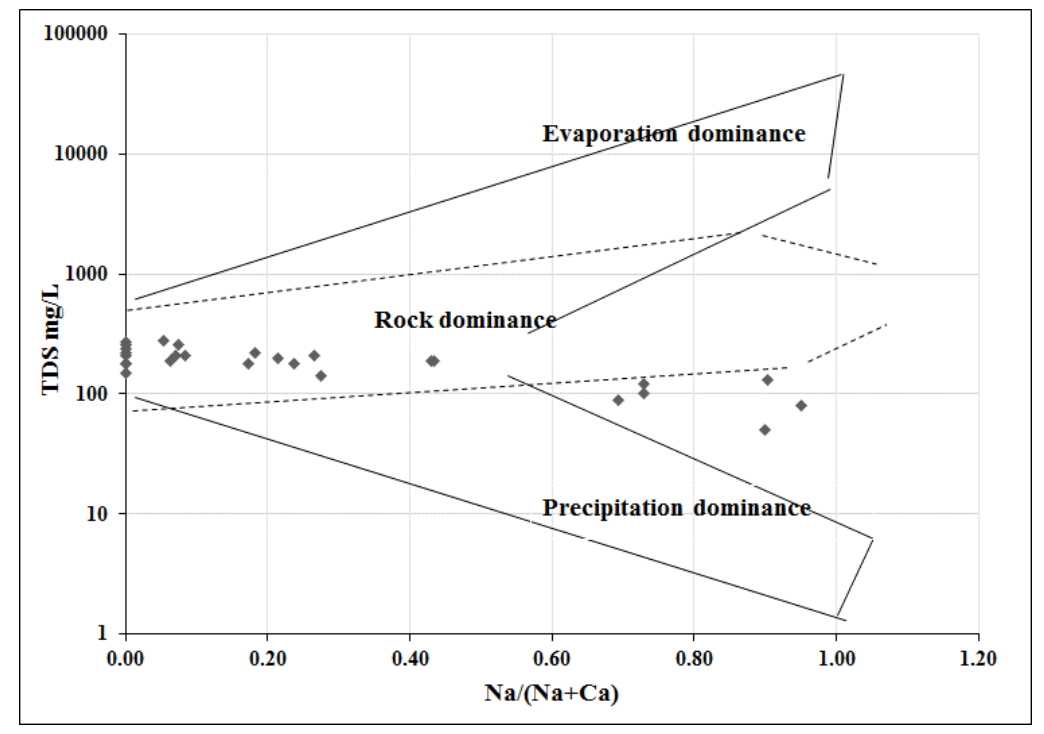

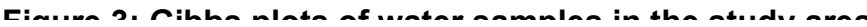




\section{DISCUSSION \\ Concentrations of Physico-chemical Parameters and Suitability of Groundwater}

Based on the $\mathrm{pH}$ values the groundwater of the area is slightly acidic with almost all water samples having $\mathrm{pH}$ values of 6.5 and below. In this regard, water from twenty-six boreholes that represented $96 \%$ of all the sampled boreholes in the area is not suitable for human consumption (SON, 2007; WHO, 2011), except if diluted to reduce the acidity. The TDS is generally low (50 $280 \mathrm{mg} / \mathrm{L}$ ) in all the locations as well as typical of groundwater from crystalline basement terrain where the rates of weathering processes and mineral dissolutions are slow (Singhal and Gupta, 1999). Water with less than $600 \mathrm{mg} / \mathrm{L}$ of dissolved solids is generally satisfactory and good for domestic usage (WHO, 1984) and many industrial purposes while water with more than $1200 \mathrm{mg} / \mathrm{L}$ of dissolved solids contain minerals that give water distinctive or offensive taste and are unacceptable in other ways (Fetter, 2007). Based on the TDS results, the groundwater of the area is classified as being fresh (Freeze and Cherry, 1979).

In comparison with recommended standards, the concentrations of cations in the groundwater from the sampled boreholes are not of health concern. Calcium being an essential element for bone and teeth development in human occurs far below the recommended limit of $2500 \mathrm{mg} / \mathrm{L}$ for drinking water. If above this level the health risk is the development of kidney stone (WHO, 2009, Table 2). Likewise, the magnesium and sodium occurred below the recommended level of 250 and $200 \mathrm{mg} / \mathrm{L}$ (WHO, 2011; SON, 2007) respectively for human consumption. However, the concentration of nitrate in the wells are on the high side in comparison with recommended limit of $50 \mathrm{mg} / \mathrm{L}$. Water from one-third of the sampled boreholes are not fit for human consumption. More so, the source of nitrate in natural water is not from dissolution of rock minerals but from contamination and agricultural activities such as application of fertilizers (Singhal and Gupta, 1999). The predominance of nitrate in groundwater of the area is really a cause for concern and it is an evidence of biological contamination of the groundwater system of the study area. Nitrate is injurious to human health particularly in infants when it occurs at toxic level. Likewise, a chloride content of more than $250 \mathrm{mg} / \mathrm{L}$ is generally objectionable for a municipal water supply, and water containing more than $350 \mathrm{mg} / \mathrm{L}$ is intolerable for most irrigation and industrial uses. Even though, water with more than $250 \mathrm{mg} / \mathrm{L}$ chloride may not pose serious harmful effect to human but it will be characterized by disagreeable taste $\mathrm{WHO}$, 2011). However, considering the fact that chlorine is commonly being used for water purification in the study area (Akanbi, 2017), and the fact that human wastes such as urine and faecal droppings are rich in chloride, it is most likely that the chloride sources in groundwater of the area are from anthropogenic inputs. The presence of fairly high amount of nitrate in the groundwater also indicated and buttressed anthropogenic source(s) for both nitrate and chloride presence in the groundwater.
Hydrogeochemical Facies and Enrichment Sources

The dominance of calcium in the groundwater is linked to weathering and dissolution of the underlying bedrock that is mainly amphibolite (Fig. 1). This is due to the fact that amphibolie is a mafic rock and is rich in ferromagnesssian minerals including plagioclase feldspars and hornblende (Akanbi, 2016). These minerals particularly the feldspars are rich in calcium, sodium and potassium. This is supported by the Gibbs plot (Fig. 3), where the majority (about $80 \%$ ) of the sample plotted within rock dominance region of the diagram, indicating that the main enrichment factor for cationic chemical facies in groundwater is weathering and dissolution of aquifers and soils along groundwater flow path. On the other hand, the contribution of rainfall to the chemical constituents of the groundwater is also fairly represented in the Gibbs diagram whereby six samples plotted along the boundary of precipitation and rock dominance zone (Fig. 3). This suggests that anionic facies such as bicarbonate and carbonate may be derived from dissolution of carbon IV oxide in the atmosphere and along the soil zone. Generally, carbonate and bicarbonate are mainly sourced from either carbonate rocks such as limestone and dolomite and/or from atmospheric origin (Singhal and Gupta, 1999). However, since the study area is mainly underlain by crystalline basement rocks, hence it can be concluded that the most likely source of bicarbonate and carbonate is precipitation. Nitrate abundance is typically biogenic and/or anthropogenic, since nitrate occurrence in groundwater is not from rock or soil dissolution. Moreover, previous work in the area (Akanbi, 2017) pronounced that both sewage and use of chlorine for water purification are the most likely major sources of chloride concentration in the groundwater of the area, which is typical of shallow groundwater system where human contamination comes in through direct recharge.

\section{Inter-relationships of Chemical Constituents}

From the result of the correlation analyses presented in Table 3, the relationships between TDS and major ions are significant and direct in most cases. Strong to moderate relationships existed between TDS and $\mathrm{Na}$, $\mathrm{Ca}, \mathrm{Mg}, \mathrm{Cl}, \mathrm{NO}_{3}$ with $\mathrm{CO}_{3}{ }^{2}$. The significant and direct relationships between TDS and most ions suggest strong influence of these chemical facies as major contribution to the dissolved solids in water, particularly with calcium with $\mathrm{R}=0.87$. The relationship of $\mathrm{TDS} / \mathrm{NO}_{3}$ is significant and direct with $R=0.56$, while the associations between nitrate and most cations are direct except with $\mathrm{Na}$. Also, nitrate has strong positive relationships with the chloride and bicarbonate but low significance with carbonate. Hence, it can be deduced that the affinity of nitrate with chloride and bicarbonate is stronger than those between nitrate, sulphate and carbonate where the significant values are low. More so, considering the fact that nitrate and chloride are known to enter the water through anthropogenic sources such as sewage, agricultural activities and from water treatment in case of the latter, the evidence that these ions are sourced from human inputs into groundwater is more or less certain in the study area. 


\section{CONCLUSION}

All the sampled hand pump boreholes were drilled primarily for domestic use. Aside the acidic nature and high nitrate content of the groundwater in most of the boreholes, the concentrations of all the analysed major ions are within the acceptable limits for drinking purpose. The variations in water types from the trilinear diagram are attributable to mineral dissolution; groundwater recharge from atmospheric precipitation; and chlorination during water treatment as well as.

\section{TABLE 3: CORRELATION (R) ANALYSIS}

\begin{tabular}{|c|c|c|c|c|c|c|c|c|c|c|c|c|}
\hline & pH & EC & TDS & $\mathrm{Ca}^{2+}$ & $\mathrm{Mg}^{2+}$ & $\mathrm{Na}^{+}$ & $\mathrm{K}^{+}$ & $\mathrm{HCO}_{3}^{-}$ & $\mathrm{CO}_{3}{ }^{2-}$ & $\mathrm{SO}_{4}{ }^{2-}$ & $\mathrm{NO}_{3}{ }^{-}$ & $\mathrm{Cl}^{-}$ \\
\hline $\mathrm{pH}$ & 1.00 & & & & & & & & & & & \\
\hline EC & -0.11 & 1.00 & & & & & & & & & & \\
\hline TDS & -0.11 & 1.00 & 1.00 & & & & & & & & & \\
\hline $\mathrm{Ca}^{2+}$ & -0.28 & 0.87 & 0.87 & 1.00 & & & & & & & & \\
\hline $\mathrm{Mg}^{2+}$ & -0.30 & 0.56 & 0.57 & 0.51 & 1.00 & & & & & & & \\
\hline $\mathrm{Na}^{+}$ & 0.17 & -0.75 & -0.76 & -0.66 & -0.59 & 1.00 & & & & & & \\
\hline $\mathrm{K}^{+}$ & 0.43 & 0.50 & 0.51 & 0.36 & 0.19 & -0.55 & 1.00 & & & & & \\
\hline $\mathrm{HCO}_{3}$ & 0.27 & 0.35 & 0.34 & 0.31 & -0.16 & 0.00 & 0.52 & 1.00 & & & & \\
\hline $\mathrm{CO}_{3}{ }^{2-}$ & -0.30 & 0.66 & 0.65 & 0.72 & 0.38 & -0.53 & 0.29 & 0.30 & 1.00 & & & \\
\hline $\mathrm{SO}_{4}{ }^{2-}$ & -0.40 & 0.44 & 0.43 & 0.59 & 0.24 & -0.35 & 0.17 & 0.34 & 0.87 & 1.00 & & \\
\hline $\mathrm{NO}_{3}^{-}$ & 0.31 & 0.55 & 0.56 & 0.56 & 0.13 & -0.43 & 0.77 & 0.56 & 0.38 & 0.25 & 1.00 & \\
\hline $\mathrm{Cl}^{-}$ & 0.06 & 0.55 & 0.53 & 0.55 & 0.32 & -0.40 & 0.56 & 0.52 & 0.31 & 0.32 & 0.59 & 1.00 \\
\hline
\end{tabular}

possible sewage leakages into the hydrologic system of the area. In the light of this, further studies in respect to microbiological content and trace elements concentration in the water should be carried out for proper water quality assessment in the study area. Additionally, in order to safeguard the groundwater of the area from direct recharge; locations, design and construction of boreholes should not only be in accordance with the hydrogeological conditions but also satisfy acceptable health standards. Also, government environmental laws should be enforced to curb open defecation in the area.

\section{REFERENCES}

Akanbi, O. A., 2016. Use of vertical electrical geophysical method for spatial characterisation of groundwater potential of crystalline crust of Igboora area, southwestern Nigeria. International Journal of Scientific and Research Publications 6.3: 399-406.

Akanbi, O.A., 2017. Hydrogeologic characterisation of crystalline basement aquifers of part of Ibarapa area, southwestern Nigeria. Ph.D. thesis. Department of Geology, University of Ibadan. Xxiv $+312 p p$.

Akanbi, O. A. and Olukowade, J.O., 2018. Lithologic characterisation of the Basement Aquifers of Awe and Akinmorin Areas, Southwestern Nigeria: Global journal of geological sciences, 16 pp.1-11. http://dx.doi.org/10.4314/gjgs.v16i1.1.

Akanbi, O. A., 2018. Hydrogeological characterisation and prospects of basement aquifers of Ibarapa region, SW- Nigeria. Appl Water Sci (2018) Vol. 8 (3):89. Springer-Berlin Heidelberg. https://doi.org/10.1007/s13201-018-0731-9.
Akinwumiju, A. S., and Olorunfemi, M. O., 2018. A GISbased aquifer vulnerability assessment in the basement complex terrain of southwestern Nigeria. Sustainable Water Resources Management 4 (4), 715-734.

Dada, S. S., 1998. Crust-forming ages and proterozoic evolution in Nigeria: a reappraisal of current interpretations. Precamb. Res.87: 65- 74.

Egboka, B. C. E., 1987. Water resources problem of Enugu area, Anambra state, Nigeria. I.AH.S. 153: 119- 125.

Fashae, O. A., Tijani M. N., Talabi A. O., and Adedeji O. I., 2014. Delineation of groundwater potential zones in the crystalline basement terrain of SWNigeria: an integrated GIS and remote sensing approach. Appl Water Sci. 4: 19-38.

Fetter, C. W., 2007. Applied hydrogeology. Second edition. Merrill Publishing Company, USA.

Freeze, R. A. and Cherry, J. A. 1979. Groundwater, Prentice Hall, Englewood Cliffs, New Jersey.

Gibbs, R. J., 1970. Mechanisms controlling world's water chemistry. Science 170, 1088-1090.

NGSA, 2009. Geological and mineral resources map of south-western zone, Nigeria. Abuja:NGSA.

Oyedele, A. A., Ayodele O. S. and Olabode O. F. 2019. Groundwater quality assessment and characterization of shallow basement aquifers in parts of Ado Ekiti metropolis, southwestern Nigeria. SN applied Sciences, 1:669. 
AKANBI, O. A., SANNI, W., OSHIN, O., AND OLATUNDE, A. G.

Piper, A. M., 1944. A graphic procedure in geochemical interpretation of water analysis. Trans Am Geophysics Union, 25, 914-928.

Singhal, B. B. S. and Gupta, R. P., 1999. Applied hydrogeology of fractured rocks. Dordrecht, The Netherlands: Kluwer Academic Publishers, 400p.

Standards Organization of Nigeria, 2007. Nigerian Industrial Standard: Nigerian Standard for Drinking Water Quality. Wuse, Abuja, Nigeria.
Tijani, M. N., 2016. Groundwater: The Buried Vulnerable Treasure. Inaugural lecture. University of Ibadan, Ibadan-Nigeria.

WHO, 1984. Guidelines for Drinking water quality, vols. 1, 2 and 3. Geneva

WHO, 2009. Calcium and magnesium in drinking-water: Public health significance J. Cotruvo and J. Bartram (Edi.). http://whqlibdoc. who.int/publications/ 2009/9789241563550_eng.pdf

WHO, 2011. Guidelines for Drinking -water quality. Geneva, Switzerland, http://www.who.int. 